\title{
A LIST OF SPIDERS FROM MONA ISLAND, WITH DESCRIPTIONS OF NEW AND LITTLE KNOWN SPECIES ${ }^{1}$
}

\author{
By Elizabeth B. Bryant \\ Museum of Comparative Zoölogy
}

The small Mona Island, between Haiti and Puerto Rico, is rarely visited by collectors and its spider fauna is little known. In 1914 Mr. N. Banks described two new species from there in a short paper published in the Bulletin of the American Museum of Natural History, and much later, 1929-1930, Dr. A. Petrunkevitch noted in his "Spiders of Porto Rico" fifteen species, of which three were new.

Recently, two small collections from Mona have been received by the Museum of Comparative Zoölogy. The first was from Dr. Serrallés of Puerto Rico, who spent a week there during April, 1944. He very kindly sent the material to me for identification. The second collection was from Mr. Harry Beatty, who spent the month of August of the same year there. Neither collection is large, either in species or specimens, but as the island is small and not very diversified, the spider fauna probably is small. Four species are new.

This paper lists the forty-one species that have been reported from Mona and includes descriptions of the four new species and the hitherto unknown form of Hentzia squamata (Petr.), with elongate mandibles. Collecting at a different season would undoubtedly add many more species.

The following is a list of the species collected by Dr. Serrallés in April and by Mr. Beatty in August 1944.

Fam. Filistatidet

o Filistata hibernalis Hentz Apr.Aug.

Fam. Ecobitder

o Ecobius benneri Petr. Apr.

1 Published with a grant from the Museum of Comparative Zoölogy at Harvard College. 
Fam. Oxyopide

o Peucetia viridans Hentz Aug.

o Oxyopes salticus Hentz Aug.

† Hamataliwa haytiana (Chamb.) Apr.

Fam. Pholcide

q Physocyclus globosus (Tacz.) Apr.Aug.

FAM. TherididD

o 9 Anelosimus studiosum (Hentz) Apr.

$\widehat{\gamma}$ ㅇ Conopistha argyrodes (Walck.) Apr.Aug.

o + Latrodectus mactans (Fabr.) Aug.

$\uparrow$ Theridion insulicola spec. nov.

Fam. Argiopid 2

pullus Aranea displicata (Hentz) Apr.

ơ ${ }^{\pi}$ Argiope argentata (Fabr.) Apr.Aug.

q Cyclosa caroli (Hentz) Aug.

\$ Eriophora (scape broken) Apr.Aug.

Edricus crassicauda (Keys.) Aug.

q Eustala anastera (Walck.) Aug.

+ Gasteracantha cancriformis (Linn.) Apr.Aug.

\& Leucauge argyra (Walck.) Apr.

o " regni (Simon) Apr.

ot $q$ Metepeira virginensis Chamb. and Ivie Apr.

+ Neoscona volucripes (Keys.) Apr.

$0^{\lambda}+$ Nephila clavipes (Linn.) Apr.Aug.

+ Parawixia cambridgei Bryant Aug.

ot $q$ Wixia serrallesi spec. nov.

Fam. Sparassidet

q Stasina macleayi Bryant Apr.

o Olios bicolor Banks Aug.

q Heteropoda venatoria (Linn.) Apr.

Fam. Selenopide

o 우 Selenops insularis Keys. Apr.Aug.

Fam. Thomiside

수 Misumenops celer (Hentz) Aug.

Fam. Clubionide

ot o Aysha tenuis (L. Koch) Apr.Aug.

o ${ }^{\pi}+$ Chiracanthium inclusum (Hentz) Aug.

† Wulfila immaculata Banks Aug.

Fam. Salticid

우 우 Habronattus translatus (Peckham) Aug. 
o $q$ Hentzia squamata (Petr.) Apr.Aug.

1 o Sidusa mona spec. nov. Aug. + Stoides placida spec. nov. Aug.

The following is a list of species reported from Mona but not seen by me.

Fam. Oxyopide

Oxyopeidon rana Simon (Petrunkevitch, 1929)

Fam. Argiopide

Argiope trifasciata (Fabr.) (Petrunkevitch, 1929)

Fam. Ctenid

Oligoctenus ottleyi Petrunkevitch (1930)

Fam. Tномisid ж

Misumenops asperatus (Hentz) (Petrunkevitch, 1930)

Fam. Salticide

Siloca minuta Petrunkevitch (1930)

Fam. TheridiId

Theridion insulicola spec. nov.

Figure 1

Female. Length, $3.0 \mathrm{~mm}$., ceph. $1.2 \mathrm{~mm}$., abd. $1.7 \mathrm{~mm}$. long, $1.6 \mathrm{~mm}$. wide.

Cephalothorax pale, shining, very slightly convex, anterior margin less than half the greatest width, widest between the third pair of legs, thoracic groove covered with a broad black line that does not reach the ocular area or the posterior margin, row of black bristles from the p.l.e. to the groove and two long median bristles between the groove and the posterior eyes; eyes cover the anterior margin, anterior row recurved, a.m.e. largest of the eight, separated by less than a diameter, and from a.l.e. by a radius, posterior row straight, eyes equidistant, lateral eyes subequal and touching, p.m.e. separated by less than a diameter, each eye surrounded by a black ring; quadrangle higher than wide and narrower behind than in front; clypeus higher than the eye area, a small median black spot on the margin; mandibles pale, shaded with gray on the median margin, long, cone-shaped, weak, groove short, fang short; labium fused to the sternum, wider than long, tip not narrowed; maxilla almost twice 
as long as the labium, slightly inclined, tips transverse; sternum pale, shaded with gray about the margins and a short median gray stripe at the tip, triangular, as wide as long, ending in a broad round tip in front of the fourth coxæ, fourth coxæ separated by more than a diameter; abdomen pale, with a short median gray spot at base, followed by a pair of converging gray spots, entire abdomen covered with black granules, each bearing a long colorless bristle, strongly convex, almost as wide as long, venter a dull yellow with small pale spots; legs, 1-2-4-3, not varying much in length, pale, with black spots on ventral side, so that the legs have a spotted appearance, no spines but rows of hairs and bristles, III and IV tibiæ with a median dorsal bristle; epigynum, area wider than long, divided by a narrow median septum, each side pale oval areas, which probably are the openings, near the posterior margin and below the surface, each side, a transverse oval sac, with a small circular sac just anterior.

Holotype $q$ Mona Island, 5 April 1944 (Serrallés).

Theridion insulicola differs from Theridion antillanum Simon, from St. Vincent, and reported by Petrunkevitch from Puerto Rico, by the smaller size, the quadrangle of median eyes narrower behind, and the black granules on the abdomen. These granules are very conspicuous, even after the long bristles have been broken off.

Fam. Argiopid

Genus Parawixia F.O.P.-Cambridge 1903

Parawixia cambridgei Bryant

Parawixia cambridgei Bryant, 1940, p. 342, figs. 104 106. " $₫$ ㅇ Cuba; Oriente, coast below Pico Turquino, June 1936" (Darlington).

This species was described from the Oriente, Cuba, and afterwards found in a collection from Diquini, Haiti, made by Dr. W. W. Mann. It has the same number of tubercles on the abdomen as Marxia grisea McCook, American Spiders, 1893, 3, p. 195, pl. 13, fig. 10, described from a female, $8.00 \mathrm{~mm}$. long, from Biscayne Bay, Florida. The two genera belong to separate sections of the family. The male of Marxia has two long bristles on the patella of the 
palpus, and both male and female have five teeth on the lower margin of the fang groove. The male of Parawixia has but one bristle on the patella of the male palpus, and the lower margin of the fang groove has but three teeth. McCook does not state the number of teeth on the fang groove and he evidently placed the species in the genus Marxia because of the abdominal tubercles. He does describe the cephalothorax rather definitely, as "divided into two low ridges by a lateral depression passing just behind the ocular quad, giving the head a lumpy appearance." These two low elevations just posterior to the eyes are even more conspicuous in the male than in the female but until the number of teeth on the fang groove on the type specimen is known, the two can best be considered as separate species.

o Mona Island, August 1944 (Beatty).

\section{Genus Wixia O.P.-Cambridge 1882}

Wixia serrallesi spec. nov.

\section{Figures 2, 3}

Male. Length, $6.6 \mathrm{~mm}$., ceph. $3.1 \mathrm{~mm}$. long, $3.0 \mathrm{~mm}$. wide, abd. $3.6 \mathrm{~mm}$. long, $2.8 \mathrm{~mm}$. wide.

Cephalothorax brown, with a broad pale median stripe from the lateral eyes to the posterior margin, anterior margin shaded with brown and a mass of white hairs posterior to the lateral eyes, a narrow marginal pale stripe, anterior margin about half the greatest width, sides evenly rounded, eye area carried foreward, cephalothorax rather flat, thoracic groove long and deep; eyes in three groups, anterior row strongly recurved, a.m.e. largest of the eight, convex, separated by about a diameter, p.m.e. slightly smaller than the a.m.e., separated by almost two diameters, a short bristle between each a.m.e. and p.m.e., lateral eyes small, subequal, on a common tubercle, a long bristle anterior and another posterior to the tubercle; quadrangle of median eyes slightly narrower behind and not as high as wide; clypeus below a.m.e. less than a diameter of a.m.e.; mandibles dark brown, vertical, small, cone-shaped, fang groove oblique, four teeth on the upper margin, the second tooth from base of the fang the small- 
est, lower margin with four small, subequal teeth; labium fused to the sternum, brown, tip rebordered and pale, wider than long; maxille brown, distal half pale, about twice as long as labium; sternum pale, triangular, threequarters as wide as long, widest between the second coxæ and pointed in front of the fourth coxæ, coxæ pale, I coxa with a hook, III and IV coxæ with a strong dark cusp or spine about the middle, IV trochanter with a cusp; abdomen oval, with a pair of well-defined tubercles between the shoulder angles that extend upwards, first pair of muscle spots between the tubercles, a median basal pale stripe heavily outlined with black spreads towards the tubercles and fades posteriorly, a vague dark spot between the second pair of muscle spots, entire abdomen with scattered long bristles, venter dark with a pair of pale spots anterior to the spinnerets; legs, 1-2-4-3, III left missing, all joints pale with broad dark bands, median on femora, basal, median and distal on tibiæ and metatarsi, spines, I pair, femur, dorsal, 3 whorls, ventral, 11 pairs, the 6 spines at the distal end of the prolateral row, very long and strong, patella, 1 at the tip, prolateral, 2, retrolateral, 1, tibia, spines scattered on the dorsal and ventral sides, metatarsus, ventral, 0, II pair, femur, dorsal, in 3 whorls, ventral, a prolateral row of 11 spines, patella same as I pair, tibia, bent, ventral, 4 pairs of strong spines with a curved tip, each from a raised base, III pair, femur, 2 small ventral spines near the base, IV pair, femur, ventral, prolateral row with 4 basal strong spines each from a raised base, retrolateral row only at the distal end; palpus not as long as the cephalothorax, patella with 1 long strong bristle, tibia about as long as wide, paracymbium long with a truncate tip, clavis long, with a broad recurved spur from the base, tip extends far beyond the cavity, embolus probably a very small, short black spur near the tip.

Female. Length, $9.0 \mathrm{~mm}$., ceph. $3.2 \mathrm{~mm}$. long, $3.0 \mathrm{~mm}$. wide, abd. $7.9 \mathrm{~mm}$. long, $5.5 \mathrm{~mm}$. wide.

Cephalothorax brown, covered with short white hairs, the pale stripe much narrower than in the male, eye area not carried forward as much as in the male; eyes same as 
in the male; mandibles brown, vertical, fang groove oblique, upper margin with three teeth, middle tooth the largest, lower margin with two widely separated teeth; mouth parts and sternum same as in the male, no spurs on coxæ or trochanter; abdomen dorsal tubercles not as distinct as in the male but the markings the same; legs, 1-2-4-3, much darker than in the male, spines, femora with 0 ventral spines, I pair, femur, dorsal, small and scattered, 3 strong prolateral spines, patella, prolateral, 2 , retrolateral, 1, tibia and metatarsus, spines small and not paired, II pair, tibial spines not modified; epigynum, chitinized area longer than wide, a wide spoon-shaped scape, deeply depressed in the middle area with the tip rebordered.

Holotype o ${ }^{\top}$ Mona Island, August 1944 (Beatty). Allotype + Mona Island, August 1944 (Beatty). Paratype o Mona Island, 6 April 1944 (Serrallés), I pair of legs missing. Paratypes 2o Mona Island, August 1944 (Beatty), probably in the penultimate moult.

The genus Wixia was based by O.P.-Cambridge in 1882, on the species abdominalis known only from the female from the Trail collection from the Amazon. In 1889, he erected the genus Amamra in the Biol. Centrali-Americana, 1, p. 55, for five species from Central America. A few years later, in the second volume of the Biol., F.O.P.Cambridge placed this genus as a synonym of Wixia but he gave no reason for so doing.

Wixia serrallesi does not agree perfectly with the definition of the genus as given by F.O.P.-Cambridge. The eyes are the same in both male and female, with the a.m.e. the largest, the clypeus is less than a diameter of a.m.e., instead of very high, the abdominal tubercles are small in both male and female. Eventually, the genus Amamra may be revived, either as a distinct genus or a subgenus of Wixia, and serrallesi would be placed with it, rather than in the genus Wixia, which has large abdominal tubercles and the quadrangle of median eyes square.

Wixia serrallesi is very near to Wixia clivosa (O.P.Camb.) known from both male and female from Mexico and placed by O.P.-Cambridge in the genus Amamra. 
Both have a very long clavis that has a circular sweep outside the cymbium and both have the median area of the scape depressed.

Fam. Salticidet

Genus Hentzia Marx 1883

Hentzia squamata (Petrunkevitch)

Wala squamata Petrunkevitch, 1930, p. 146, figs. 130 134. "several o's and is, from Mona Island, 24 February 1914, in the collection of the American Museum of Natural History."'

The specimens described by Dr. Petrunkevitch all had the short vertical mandibles. Six males and six females were collected by Beatty in August, 1944. Three of the males have the short mandibles and the others have mandibles of varying length. When the mandibles are long and porrect, the two teeth on the promargin are widely separated, one near the base of the fang and the other near the base of the joint. The large tooth on the retromargin is much nearer the tooth at the distal end, than to the second tooth that is almost hidden by the scopula of the maxillæ. The largest male is $6.0 \mathrm{~mm}$. long with the cephalothorax, $2.5 \mathrm{~mm}$. long and $2.2 \mathrm{~mm}$. wide. The mandibles are $2.0 \mathrm{~mm}$. long, with the outer margins parallel and fringed with long white hairs; the inner margins are touching on the basal quarter and then gradually narrow to the width of the fang. On the specimens with the long, porrect mandibles, the fang is longer than the basal joint with the distal third very slender and curved.

In all specimens of females, the mandibles are vertical, rather thick, with a large bicuspid tooth on the retromargin. A large female is $6.7 \mathrm{~mm}$. long.

The species is very close to Hentzia peckhami (Cockerell), 1893, from Jamaica, (Anoka moneagua Peckham, 1894). This species is smaller and all of the type specimens of the Peckham species from Moneague, have short mandibles, with no white scales, either on the mandibles or on the cephalothorax. The females are also small and dark. The epigynes are very similar. 


\section{Genus Stoides Simon 1901 \\ Stoides placida spec. nov. \\ Figure 4}

Female. Length, $3.4 \mathrm{~mm}$., ceph. $1.5 \mathrm{~mm}$., abd. $2.1 \mathrm{~mm}$.

Cephalothorax dark brown, ocular area covered with golden iridescent scales, a large pale transverse spot, twice as wide as long on slope posterior to the dorsal eyes, probably in life covered with white scales as a few remain on the lateral margins, a few white scales on margin above the posterior legs, clypeus with white scales, cephalothorax very high, widest posterior to the dorsal eyes, in a lateral view, slightly depressed posterior to the ocular area, then sloping very gradually to near the posterior margin where it falls abruptly, thoracic groove very short and faint; eyes, anterior row recurved, so that the posterior margins form a straight line, the eyes inclined downward, so they can not be seen from the dorsal view, a.m.e. very large, almost touching, a.l.e about a radius of a.m.e. and separated from them by less than a diameter of a.l.e., eyes of the second row midway between the first and third rows, eyes of the third row subequal with a.l.e. and on the extreme margin of the carapace; quadrangle slightly narrower behind than in front and about twothirds as long as wide; clypeus retreating, about twothirds as wide as the diameter of a.m.e., with a long recurved bristle between a.m.e.; mandibles brown, with many white scales, rather small, cone-shaped, fang groove short, no teeth on either margin, fang short with a very thick base; labium pale, longer than wide, tip pointed; maxilla pale, one and a half times as long as labium and inclined; sternum pale brown, about as long as wide, convex, fourth coxæ almost touching; abdomen a broad oval, dorsum flat with scattered scales and white hairs and longer dark hairs or bristles, a short dark basal band, followed by a pale brown median stripe with irregular margins, on anterior half a pair of large brown spots, followed on the posterior half by a pair of darker brown spots, venter pale with three narrow brown stripes, spinnerets pale, long, closely grouped and extending some distance from the abdomen; palpi pale, patella and tip of 
femur with white scales; legs, 4-3-1-2, pale, femora with basal and distal dark rings, more distinct on ventral side, posterior tibiæ with basal and distal dark rings, scattered white iridescent scales on distal joints, spines, I pair, no patella spines but a long trichobothria at the tip, tibia, dorsal, 0, ventral, 2 distal, 1-1r, prolateral, 1, metatarsus, dorsal, 0, ventral, 2-2, II pair the same as I pair, III and IV pairs, patellæ with prolateral and retrolateral spines, a dorsal basal spine on tibiæ, tibiæ spiny, metatarsi with three whorls of spines; epigynum, the pair of spermatheca separated by almost two diameters, with smaller sacs just anterior which are separated by about a diameter, between the two sacs a depressed area.

Holotype $q$ Mona Island, August 1944 (Beatty).

The genus Stoides was based by Simon on Prosthesima pygmea Peckham from St. Vincent. Later the Peckhams added to the genus, Attus auratus Hentz, common in the southern part of the United States. It is questionable if the latter species belongs in the genus. The types of Prostheclina pygmea, both male and female, were probably returned to the British Museum and the co-types, an adult female and an immature specimen, retained by the Peckhams and are now in the Museum of Comparative Zoölogy collection. They are old and very much rubbed but probably once had hairs and scales on the cephalothorax. In the female the second row of eyes is plainly midway between the first and third rows as stated by the Peckhams. Simon in the description of the genus, places the eyes of the second row nearer the third than to the first row. Stoides placida is congeneric with Stoides pygmea (Peck.). It is slightly larger and has the anterior row of eyes more retreating so that the eyes are not visible from the dorsal side.

\section{Genus Sidusa Peckham 1895}

Sidusa mona spec. nov.

Figures 5, 6

Male. Length, $4.5 \mathrm{~mm}$., ceph. $2.4 \mathrm{~mm}$. long, $1.6 \mathrm{~mm}$. wide, abd. $2.1 \mathrm{~mm}$.

Cephalothorax dark brown, ocular area covered with white scales with scattered dark bristles, the white scales 
extend in a long point behind the dorsal eyes half way to the posterior margin, marginal stripe of white scales, cephalothorax moderately high, highest posterior to the dorsal eyes, widest posterior to the dorsal eyes, posterior margin about two-thirds as wide as the anterior, thoracic groove short, in a shallow depression covered with white scales; eyes cover about one-third of the carapace, anterior row strongly recurved, a.m.e separated by little more than a line, a.l.e. about a radius of a.m.e., separated from them by less than a radius of a.l.e., second row of eyes midway between first and third rows, third row of eyes slightly narrower than the first row, eyes not on extreme margin, subequal with a.l.e.; quadrangle about half as wide as long; clypeus slightly protruding, about as wide as a radius of a.m.e.; mandibles brown, vertical, rather short, promargin of fang groove with 3 teeth near the median margin, retromargin poorly defined with no teeth, fang with a heavy base, as long as groove; labium pale brown, about as wide as long; maxille pale, about one and a half times as long as labium; sternum dark brown, with a few long white hairs, three-fifth as wide as long, first pair of coxæ separated by a little more than a diameter, fourth pair almost touching; abdomen oval, covered with short white hairs and longer dark bristles, a pair of wide dark stripes, heavier at the base show beneath the white hairs, venter pale; legs, 4-1-3-2, pale, with white scales and longer dark hairs, I pair with a prolateral dark mark on the tibia, IV pair with the femur darker at the tip, spines, I pair, patella, prolateral, 1, tibia, dorsal, 0 , ventral, 2-2, followed by 1r, retrolateral, 0, prolateral, 1-1, metatarsus, ventral, 2-2, II pair, patella, lateral, 2, tibia, ventral, 2 distal followed by 1-1r, prolateral, 1-1, retrolateral, 1, metatarsus, ventral, 2-2, retrolateral, 1, III and IV pairs with dorsal basal spine on tibiæ, patellæ with prolateral and retrolateral spines, whorl at the tip of the metatarsi; palpus about as long as cephalothorax, femur and patella pale, covered with white scales, tibia and cymbium darker, both with many long dark hairs, tibia but little longer than the patella, about as wide as long, tibial apophysis a long slender spine parallel to the cym- 
bium and almost reaches the tip of the palpal organ, palpal organ small and confined to the basal two-thirds of the joint, embolus a strong black spine with a heavy base and does not extend beyond the cavity.

Female. Length, $5.5 \mathrm{~mm}$., ceph. $2.6 \mathrm{~mm}$. long, $2.0 \mathrm{~mm}$. wide, abd. $3.6 \mathrm{~mm}$. long, $2.1 \mathrm{~mm}$. wide.

Cephalothorax brown, covered with white scales and longer dark bristles in the eye area, widest just posterior to the dorsal eyes; eyes same as in the male; clypeus covered with white hairs, less than a diameter of a.m.e.; mandibles pale brown, vertical, promargin of the fang groove with three teeth, retromargin with no teeth; sternum and mouth parts same as in the male; abdomen oval, covered with white hairs and longer dark bristles, with the pair of broad lateral dark stripes showing under the white hairs as in the male, on the posterior half the dark stripes broken into two pairs of spots, venter pale; palpi pale, covered with white hairs ; legs, 4-1-3-2, pale with a dark prolateral spot near the tip of the first femur, spines the same as in the male; epigynum shows little exterior structure, two lobes with deeply chitinized margins and dark spermatheca near the posterior margin.

Holotype ô Mona Island, August 1944 (Beatty). Allotype $q$ Mona Island, August 1944 (Beatty). Paratypes

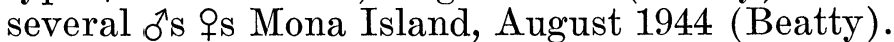

Sidusa mona is closely related to Sidusa pavida Bryant, from the Virgin Islands. The former has the tibial apophysis of the palpus much longer and the embolus heavier. Neither belong to the genus Sidusa in the sense used by either Peckham or Simon, as there is no tooth on the retromargin of the fang groove and there is a dorsal basal spine only on the posterior tibiæ. But F.O.P.Cambridge has placed in the genus several of the Peckham genera that eventually may be recognized.

Banks, N.

Literature Cited

1914. New West Indian Spiders. Bull. Amer. Mus. Nat. Hist., 33 : 637-642, pl. 43 .

Bryant, Elizabeth B.

1940. Cuban Spiders in the Museum of Comparative Zoology. Bull. Mus. Comp. Zool., 86: 249-532, pls. 1-22. 
1942. Notes on the Spiders of the Virgin Islands. Bull. Mus. Comp. Cambridge, F.O.P. Zool., 89: 317-363, pls. 1-3.

1899-1905. Arachnida; Araneides and Opiliones. 2: XII +610 , pls. 1-54. Biologia Central-Americana.

Cambridge, O.P.-

1889-1902. Arachnida; Araneidea, 1: XV +317, pls. 1-39. Biologia Central-Americana.

McCook, Henry C.

1893. American Spiders and Their Spinning Work. Philadelphia, 1: 1-284, pls. $1-30$.

Petrunkevitch, Alexander

1929-1930. The Spiders of Porto Rico. Trans. Conn. Acad., 30: 1-355, figs. $1-240 ; 31$ : 1-191, figs. 1-168.

\section{Explanation of Plate 4}

Fig. 1. Theridion insulicola spec. nov., epigynum.

Fig. 2. Wixia serrallesi spec. nov., left palpus, ventral.

Fig. 3. Wixia serrallesi spec. nov., epigynum.

Fig. 4. Stoides placida spec. nov., epigynum.

Fig. 5. Sidusa mona spec. nov., left palpus, ventral.

Fig. 6. Sidusa mona spec. nov., epigynum. 


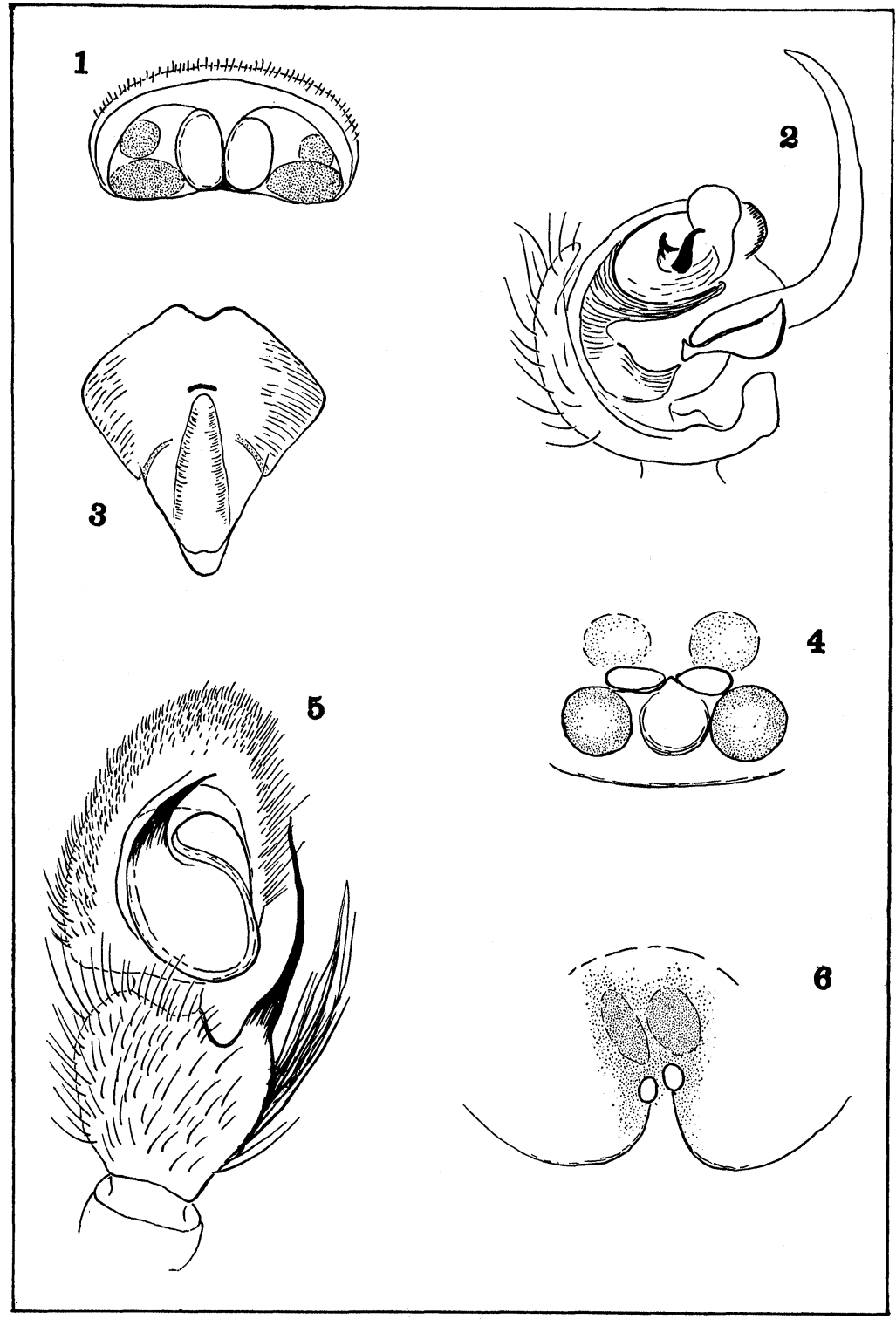

BRYANT-SPIDERS FROM MONA ISLAND 

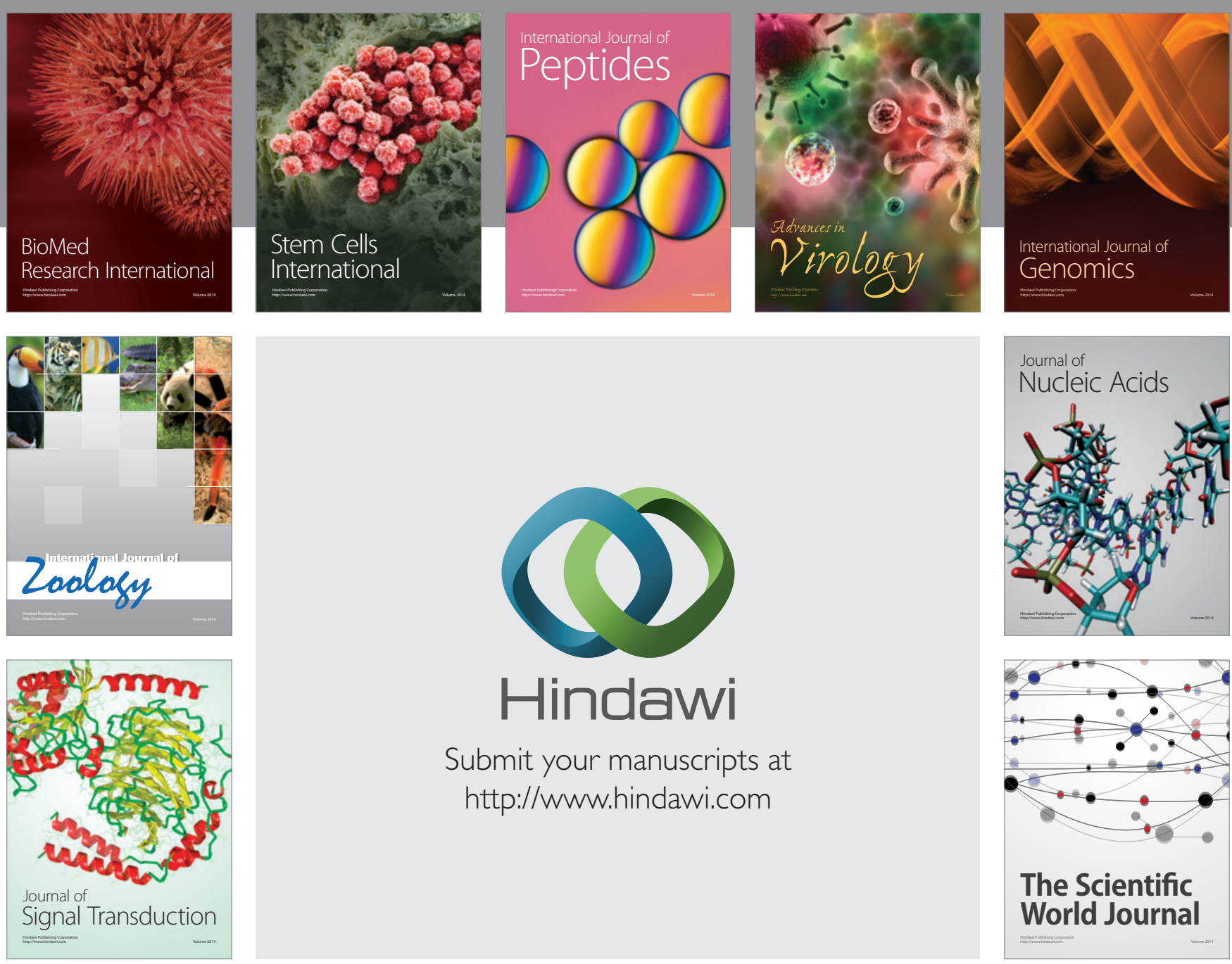

Submit your manuscripts at

http://www.hindawi.com
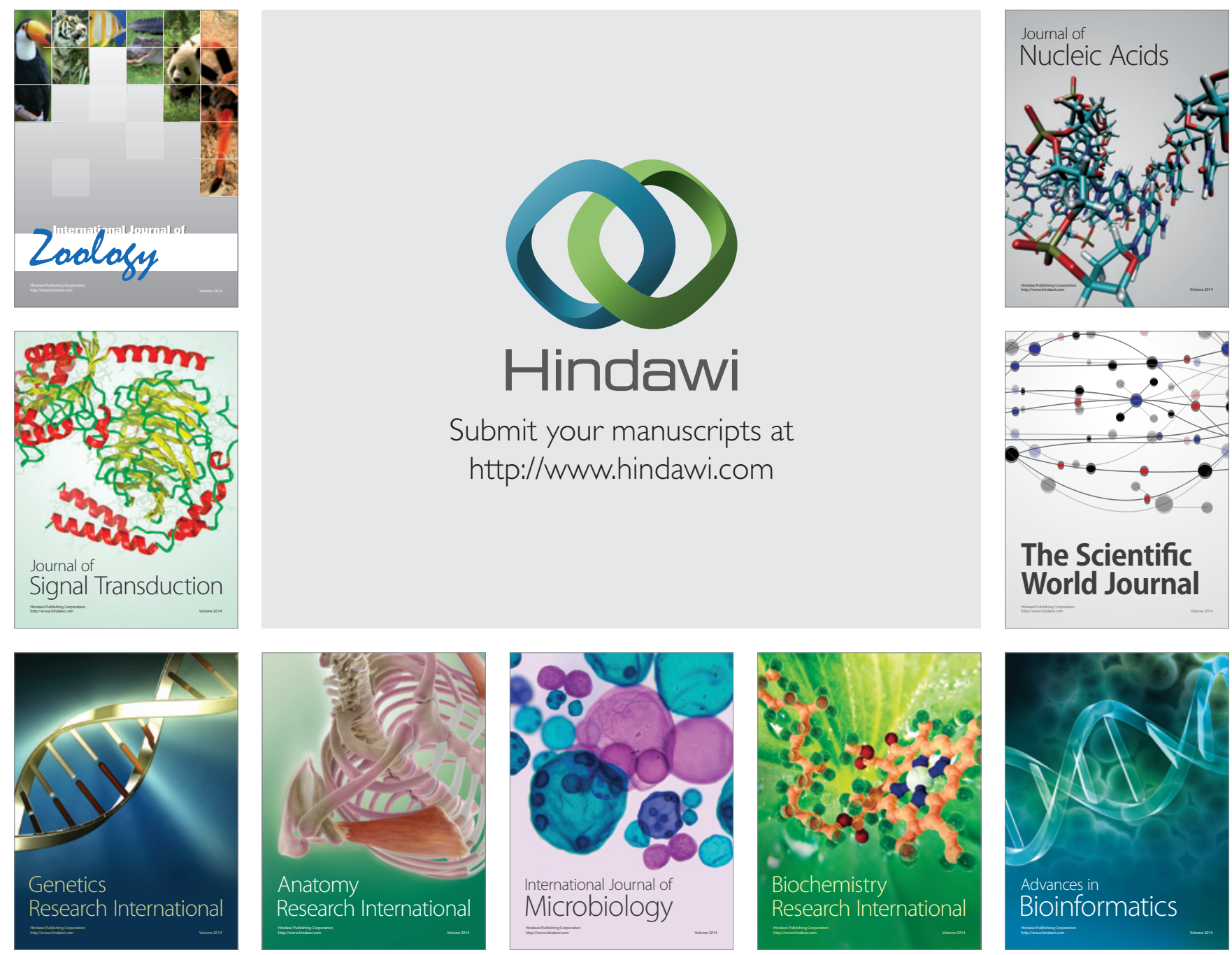

The Scientific World Journal
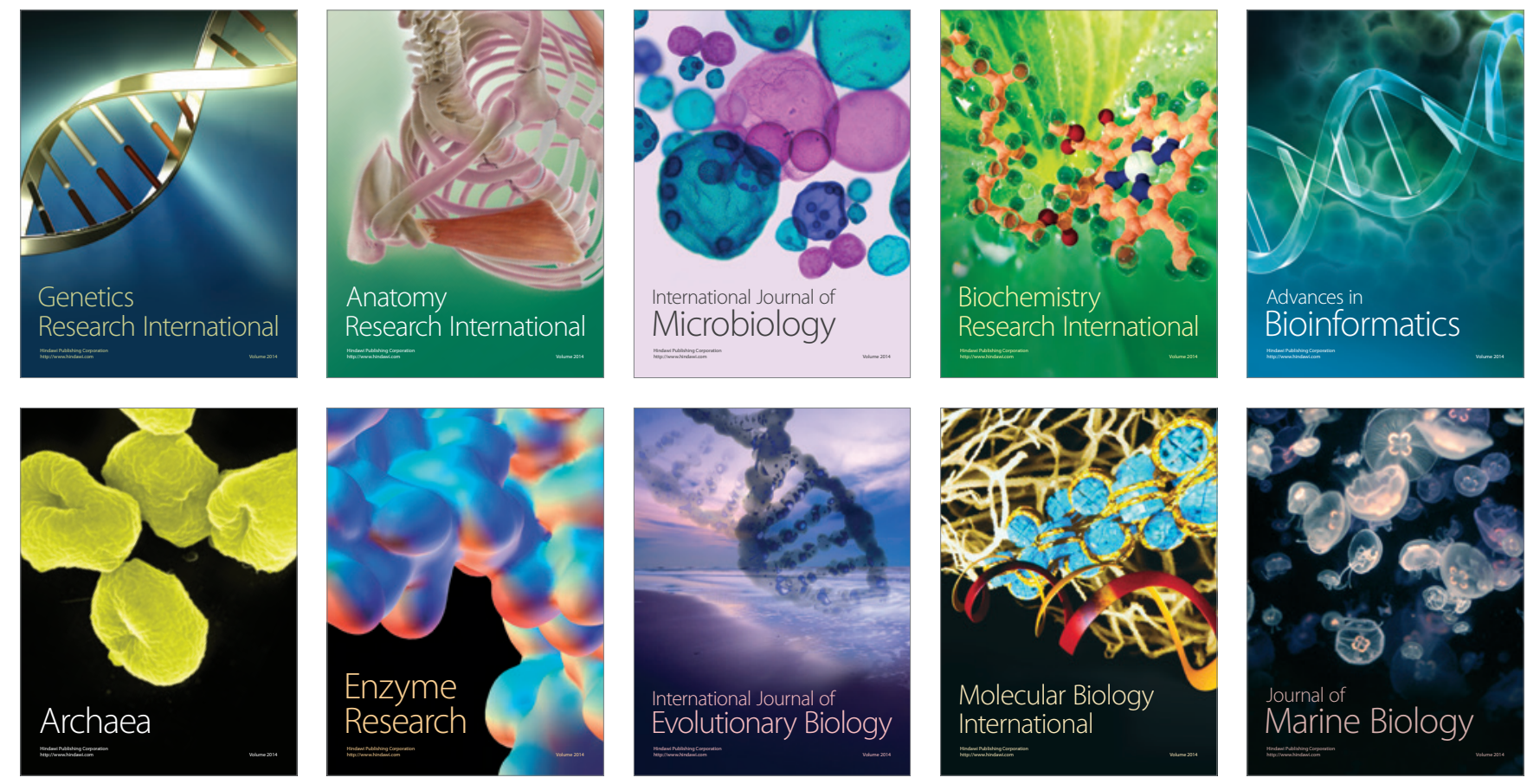